\title{
HABITAT DESCRIPTION, HOST PREFERENCE AND REPRODUCTIVE BEHAVIOR OF TUSSOCK MOTH, ORGYIA DUBIA TAUSCH. (LEPIDOPTERA: LYMANTRIIDAE), AT THE EGYPTIAN NORTHWESTERN COAST
}

\author{
Imam, I. Ahmed* and Amany N. Mansour \\ Desert Research Center, Plant Protection Department, El-Matareya, \\ Cairo, Egypt \\ *E-mail: aiimmam8@gmail.com
}

T ussock moth, Orgyia dubia Tausch. (Lepidoptera: Lymantriidae), is a rarely encountered species in the Northwestern coast of Egypt. The disturbance of its natural habitat due to different anthropogenic activities may negatively affect its population and consequently its role in the environment. So, the current study targeted different characteristics of this species to clarify certain points that could participate in the conservation of its population under the wild life and also to prevent its outbreak on the cultivated hosts. In the wild, O. dubia larvae were recorded eating Horsetail knotweed; Polygonume equisetiforme Sibth. and Sm. and Mediterranean saltbush; Atriplex halimus L. in the valleys extending along the coast. The larvae were mainly found during winter seasons. These plant hosts grew in the shallow saline soils along the plain zones of valley's upstream and along the basement portion of its terraces. The larva was also detected feeding on some cultivated plants (Old man saltbush; A. nummularia L and quinoa; Chenopodium quinoa Willd.). Laboratory test revealed that $O$. dubia larvae were more likely to attack $A$. nummularia than $C$. quinoa. The larvae exhibited high abundance on its cultivated hosts during winter seasons. Observations of laboratory-reared $O$. dubia revealed its unique reproductive behavior among the rest of lepidopteran families.

Keywords: wingless moth, saline plants, natural habitat, host preference, valleys

The Northwestern coast of Egypt is considered a unique area because of its prevailing environmental conditions (sub-arid climate conditions), land topography, natural resources and land-use types. Both topography and water

The $1^{\text {st }}$ Conference of Plant Protection Science Applications for Sustainable Development of Desert Areas "Effect of Climate Change on Plant Pests and Biodiversity in Desert Environment" 19-20 October, 2019, Cairo-Egypt. 
budget govern land use (either naturally occurring or cultivated plant cover) and, consequently, the diversification and distribution of associated insect communities. The land topography of this coastal area naturally declines northwards to the sea. Based on this elevational change, the area is divided into four main geomorphic regions: elevated tableland (plateau) to the south, piedmont plain, northern coastal plain and drainage basins (i.e., valleys or wadis) (Fig. 1). The valleys transect the elevated tableland towards the Mediterranean Sea (Yousif et al., 2013). The absence of permanent water resources is one of the main challenges faced by local communities and requires careful management of rainwater to meet the demands of drinking and irrigation (rain-fed agriculture) (Sewidan, 1978 and El Bastawesy et al., 2008). Consequently, fig and olive orchards has expanded substantially in the coastal plain as the main fruit crops due to their drought tolerance. Outside of the valleys, other crop plants such as barley, wheat, quinoa, Atriplex and some vegetables could be cultivated depending on rainfall frequency. As there are no agriculture practices implemented in the upstream and escarpment area of the valleys, certain endemic floral species that need low water requirements and can tolerate both soil salinity and environmental harsh conditions are naturally grown therein (Yousif et al., 2013). These surrounding environmental conditions with its habitat characteristics could be in favor of the occurrence of certain insect species and/or communities. A significant correlation between both distribution and diversification of the endemic hymenoptera and the habitat features along Habis valley at the Egyptian Northwestern Coast had been found (Mansour and Imam, 2017). The findings proved that each habitat along the valley with its own features such as its elevation, plant cover, topography and received rainwater amount govern the harbored insect species and/or communities.

Winter 2014 coincided with the first observation of certain lepidopteran larvae that were later identified following the laboratory emergence of its adult moths as the tussock moth, Orgyia dubia Tausch. (Lepidoptera: Lymantriidae). O. dubia larvae were observed harboring certain un-rehabilitated (un-reclaimed) zones along the valley and never detected in the cultivated ones (olive groves and fig orchards). In February 2014, Orgyia larvae had been also observed to attack the economic cultivation of old man saltbush, Atriplex nummularia L. and quinoa, Chenopodium quinoa Willd. that most Bedouins in this area planted for domestic purposes. The common names of $A$. nummularia and $C$. quinoa among Matrouh's local communities are Qataf and quinoa, respectively. O. dubia is one of the rare lepidopteran species in Egypt (Hafez and El-Said, 1970 and Hegazi et al., 1980) in Alexandria, Damietta and Kafr El-Dawar governorates before they become urbanized areas. So, this is the first documentation of this species in the Northwestern coast of Egypt. Accordingly, the current study aimed to survey all zones along the Habis valley to highlight the features of this area that make it a suitable habitat for O. dubia. The study also determined the plant hosts of

Egyptian J. Desert Res., 69, Special Issue, 15-31 (2019) 
this species under both naturally occurring and cultivated habitat conditions. In addition, laboratory studies of the host preference and reproductive behavior of $O$. dubia were carried out.
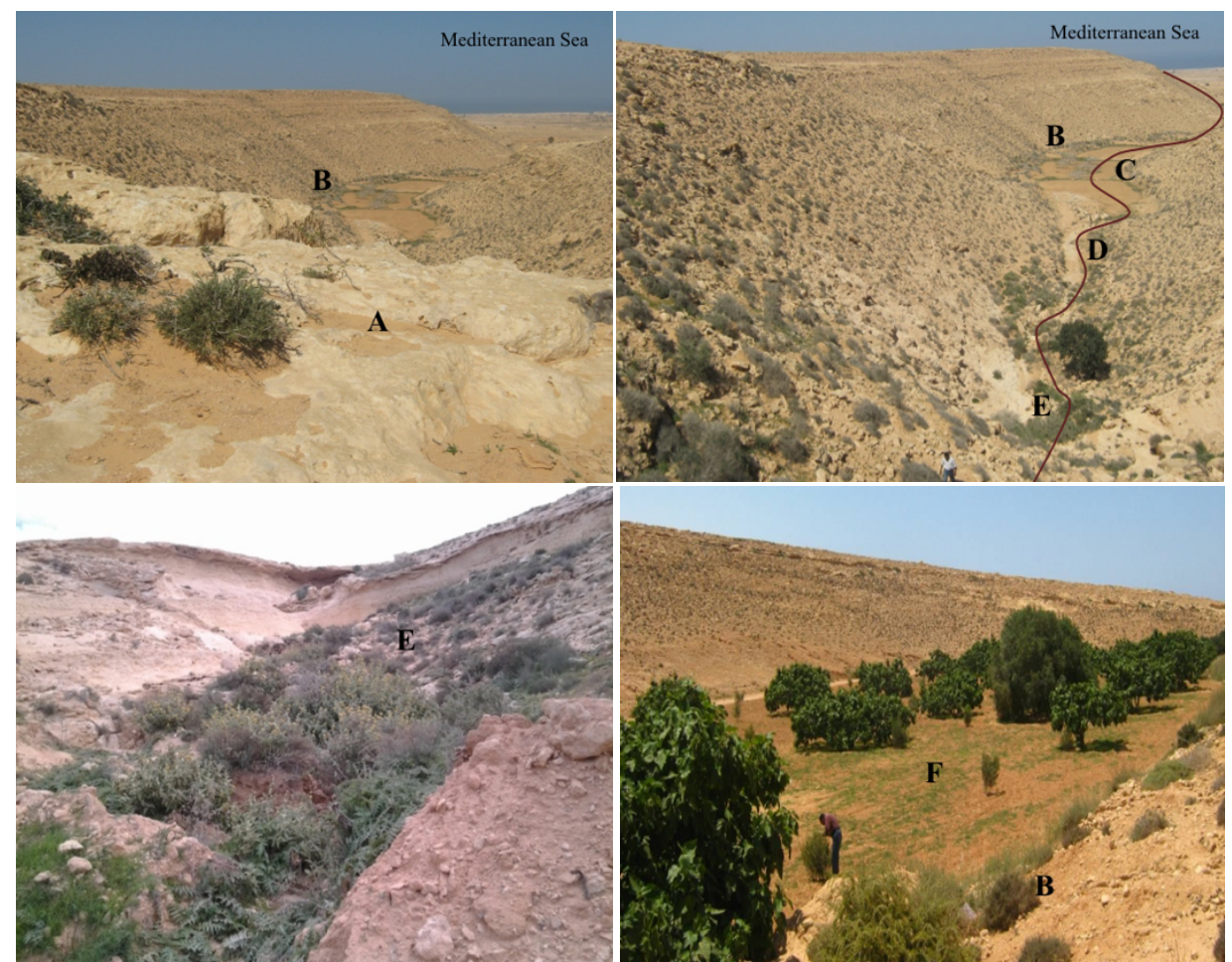

Fig. (1). Zones of the Habis valley.

A: Tableland (plateau), B: Terraces, C: Drainage basin (valley), D: Piedmont plain, E: Escarpment area (upstream), F: Northern coastal plain (downstream)

\section{MATERIALS AND METHODS}

\section{Habitat Description of $O$. dubia Larval Stage and Its Monitoring on the Wild Hosts}

For crucial description of $O$. dubia larval habitat, the upstream, midstream, downstream and terraces of Habis valley $\left(27^{\circ} 0^{\prime} 27.04^{\prime \prime} \mathrm{E}\right.$ and $31^{\circ}$ $20^{\prime} 55.07^{\prime \prime} \mathrm{N}$ ) were subjected to monthly survey schedule in 2015 and 2016. Survey was carried out through visual inspection of the naturally growing plants. During the survey process, the detected $O$. dubia larval stages were counted and handpicked, the harbored hosts were documented and the features of the larval habitat were also described. 


\section{Field Monitoring of $\boldsymbol{O}$. dubia on Cultivated Hosts}

Both saltbush, A. nummularia, and quinoa, C. quinoa, are cultivated in the study region for agricultural purposes. As both plants were observed to host Orgyia larvae, the seasonal abundance of $O$. dubia on these cultivated hosts was monitored throughout 2016 and 2017. Each host was inspected three times per season (winter, spring, summer and autumn) using a quadrate rectangle $\left(50 \mathrm{~cm}^{2}\right)$ (i.e.,12 inspections/ year) to estimate the seasonal average larval count.

\section{Rearing and Host Preference of $\boldsymbol{O}$. dubia Under Laboratory Conditions}

$O$. dubia larvae were obtained from the cultivated A. nummularia $(60$ larvae). The larvae were then placed in $3 \mathrm{~L}$ plastic rearing cages (10 larvae/ cage) and continuously provided with fresh $A$. nummularia branches as a food source. Pieces of tissue paper were added to each cage to adjust the humidity. Rearing cages were periodically checked to remove larval feces and to provide fresh $A$. nummularia branches. Larvae were left to pupate and emerged adults were sexed and then transferred to new chimney glass for egg-laying. Rearing was carried out under ambient laboratory conditions $\left(27 \pm 2^{\circ} \mathrm{C}\right.$ and $\left.79 \pm 2 \mathrm{RH}\right)$.

To test the host preference of $O$. dubia larvae, 20 newly hatched larvae were placed in the center of a $40-\mathrm{cm}$ diameter plastic dish. Equal amounts $(\sim 50 \mathrm{~g})$ of fresh $C$. quinoa and A. nummularia had previously been placed in each half of the dish. The number of larvae on each plant species was counted over two days till they reached the full-grown forms (Leddy et al., 1993). The experiment was replicated three times under ambient laboratory conditions $\left(27 \pm 2^{\circ} \mathrm{C}\right.$ and $\left.79 \pm 2 \mathrm{RH}\right)$.

\section{Reproductive behavior of $\boldsymbol{O}$. dubia Under Laboratory Conditions}

During rearing of $O$. dubia in the laboratory, daily observations were made to record features of the different life-history stages of this species. Twenty fully formed silk cocoons were selected for additional observations relating to the behavior and features of the reproduction process (i.e., mating, oviposition, egg hatching and pupation). Ten of the cocoons were dissected to follow up the pupal development; and egg deposition of the sessile female, whereas the other ten were allowed to develop naturally.

\section{RESULTS}

\section{Habitat Description of $O$. dubia Larval Stage and Its Monitoring on the Wild Hosts}

All zones of Habis valley were seasonally explored at 2015 and 2016 seasons searching for the larval stages of $O$. dubia and when detected, their counts were recorded and the habitat features were precisely described. As shown in table (1), O. dubia larvae were recorded feeding on leaves of the Horsetail knotweed Polygonum equisetiforme Sibth. and Sm. (Family: 
Polygonaceae). The vernacular name of $P$. equisetiforme among Matrouh local communities is Qordaab (El-Zanaty et al., 2010). The larvae were mainly encountered during the winter (a total of 14 and 18 larvae during the 2015 and 2016 seasons, respectively), with fewer larvae present during the autumn and fewer still during the spring. Larval abundance was lowest during the summer in both study years. During the study period, P. equisetiforme was observed to grow in a solitary and scattered pattern in the upstream of Habis valley in shallow soils where there is moderate rainfall runoff and small puddles of water occur. These shallow puddles evaporate during sunny days, leaving a small amount of moderately saline soil particles that provide an appropriate habitat for $P$. equisetiforme plants and, therefore, O. dubia.

O. dubia larvae were also detected on naturally occurring Mediterranean saltbush, Atriplex halimus L. (Family: Amaranthaceae) on terraces downstream in the Habis valley with a seasonal incidence pattern similar to that observed on P. equisetiforme (Table 1). The plant has a dense growing pattern. The downstream area of the Habis valley is characterized by the low percolation of rainwater and sediment-loaded soils, which constitute a suitable niche for $A$. halimus growth. By contrast, mid-stream and downstream areas of the Habis valley that have been reclaimed and planted with olive groves and fig orchards were found unsuitable as habitats for $O$. dubia.

\section{Field Monitoring of $\boldsymbol{O}$. dubia on Cultivated Hosts}

There has been agricultural expansion of both A. nummularia, as an animal food supplement (Alicata et al., 2002) and C. quinoa, because of its high nutritional value (FAOSTAT, 2013), along the Northwestern coast of Egypt. This expansion might favoured outbreaks of $O$. dubia, which invades the entire canopy of these cultivated plants. As shown in table (2), the number of Orgyia larvae on these cultivated hosts varied with the season, as also found on their natural hosts. The seasonal growth of both cultivated plant species is likely to explain the patterns of larval occurrence recorded in this study. $O$. dubia larvae are more likely to feed A. nummularia than $C$. quinoa because the former is a perennial, whereas the latter is an annual. As a result of the climate along the Northwestern coast of Egypt, the growth season for $C$. quinoa starts with planting in October/ November and ends with harvesting in March/April, whereas A. nummularia is grown all year round. On both host plants, the larvae were most abundant during the two winter periods (81 and 35 individuals and 86 and 37 individuals on A. nummularia and C. quinoa during winter 2016 and winter 2017, respectively). Conversely, O. dubia was rarely observed on $A$. nummularia during the summer or on C. quinoa during the autumn. 


\section{Host Preference and Reproductive Behavior of $O$. dubia Under Laboratory Conditions}

The previous observations clarified variable larval numbers inhabiting both cultivated hosts. As shown in table (3), O. dubia larvae showed an overall preference for $A$. nummularia over $C$. quinoa. The mean number of larvae that migrated to $C$. quinoa was never more than two throughout the study period. Both early and intermediate larval instars migrated towards $C$. quinoa branches, whereas, once fully grown, the larvae preferred A. nummularia as a host. Pupae were detected on A. nummularia but not on C. quinoa (Table 3).

To examine the reproductive behavior of $O$. dubia under laboratory conditions, ten fully formed silken cocoons were torn, and another ten were left intact. Two different pupal forms were found within the torn cocoons. One pupal form was the obtect pupa, which is the typical pupal form of order Lepidoptera. Only males emerged from this type of pupae. The males emerged from the cocoon by puncturing a hole in its wall using their mouthparts and forelegs. By contrast, the second pupal form was morphologically distinct from male pupae; it was a little bit bigger in size. Only O. dubia females emerged from this second form of pupae. The pupal period of the female moths ended once the puparium had been shed by the newly emerged female. However, the sessile females remained inside the cocoons, making it difficult for the males to reach and copulate with them. Once a male moth had located a female cocoon, it turned the cocoon around several times, touching it with its forelegs and antennae, possibly to detect a suitable weak point to penetrate through. Immediately after finding a suitable point, the male rested for a short period and then used its mouthparts to open a minute hole through the cocoon, enlarging it by using its forelegs and mouthparts. The male then pushed in its head inside the cocoon, and continued to use its forelegs to enlarge the hole until its whole body could enter. The penetration process took $\sim 30 \mathrm{~min}$. The male remained within the cocoon, where it copulated with the female. This took $\sim 20 \mathrm{~min}$. Thereafter, the male punctured an exit hole so that it could leave the female's cocoon. Thus, cocoons in which the female had mated were characterized by two holes, an entrance and an exit hole. Seven days later, mated females began to lay their eggs. To monitor oviposition more precisely, the cocoons that housed the females were opened. A female moth lays approximately six eggs daily on the average and oviposition finished within approximately 11 days. $O$. dubia females had a moderate fecundity pattern, with a mean of 67 eggs/ female. The females died 1 to 2 days after completing oviposition. The incubation period lasted $\sim 20$ days, where $92 \%$ of eggs hatched. Five to ten min. after hatching, the larvae aggregated and fed on the body of their mother, which provided their initial source of nourishment. Neonate larvae were also observed chewing the egg chorion. Notably, the cocoon was not targeted by the larvae. The larvae had completely consumed the body of their mother within approximately 5 days. Neonate $O$. dubia 
larvae that had hatched within the intact cocoons were observed leaving the maternal cocoon through the holes made previously by the male moth. All the moth pairs established in the laboratory mated successfully, apart from one. In the latter case, a female moth that had been removed from her cocoon was placed in a new Chimney glass with a male moth. However, although the male detected the female, they didn't copulate (Fig. 2). This female was observed to lay unfertilized eggs. The deposited eggs didn't hatch at all.

Table (1). Seasonal abundance of $O$. dubia larvae on the natural hosts; knotweed, $P$. equisetiforme and saltbush, A. Halimusin 2015 and 2016.

\begin{tabular}{|c|c|c|c|c|c|c|c|c|c|c|c|c|c|}
\hline \multirow{2}{*}{$\begin{array}{c}\text { Natural } \\
\text { host } \\
\text { species }\end{array}$} & \multirow{2}{*}{$\begin{array}{l}\text { Study } \\
\text { season }\end{array}$} & \multicolumn{12}{|c|}{ Number of larval $O$. dubia } \\
\hline & & \multicolumn{3}{|c|}{ Winter } & \multicolumn{3}{|c|}{ Spring } & \multicolumn{3}{|c|}{ Summer } & \multicolumn{3}{|c|}{ Autumn } \\
\hline \multirow{5}{*}{ 总 } & \multirow{3}{*}{2015} & Dec. & Jan. & Feb. & Mar. & April & May & June & July & Aug. & Sep. & Oct. & Nov. \\
\hline & & 5 & 4 & 5 & 2 & 2 & 1 & 1 & 1 & 0 & 1 & 1 & 1 \\
\hline & & \multicolumn{3}{|c|}{$14^{*}(4.67)^{* *}$} & \multicolumn{3}{|c|}{$5(1.67)$} & \multicolumn{3}{|c|}{$2(0.67)$} & \multicolumn{3}{|c|}{$3(1.00)$} \\
\hline & & 6 & 7 & 5 & 3 & 2 & 2 & 1 & 0 & 0 & 0 & 1 & 1 \\
\hline & 2016 & \multicolumn{3}{|c|}{$18(6.00)$} & \multicolumn{3}{|c|}{$7(2.33)$} & \multicolumn{3}{|c|}{$1(0.33)$} & \multicolumn{3}{|c|}{$2(0.67)$} \\
\hline \multirow{4}{*}{ 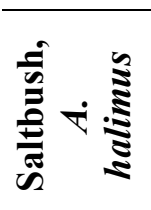 } & \multirow{2}{*}{2015} & 4 & 2 & 2 & 0 & 1 & 1 & 0 & 0 & 0 & 0 & 1 & 0 \\
\hline & & \multicolumn{3}{|c|}{$8(2.67)$} & \multicolumn{3}{|c|}{$2(0.67)$} & \multicolumn{3}{|c|}{0} & \multicolumn{3}{|c|}{$1(0.33)$} \\
\hline & \multirow{2}{*}{2016} & 3 & 1 & 0 & 1 & 1 & 1 & 0 & 1 & 0 & 0 & 0 & 0 \\
\hline & & \multicolumn{3}{|c|}{$4(1.33)$} & \multicolumn{3}{|c|}{$3(1.00)$} & \multicolumn{3}{|c|}{$1(0.33)$} & \multicolumn{3}{|c|}{0} \\
\hline
\end{tabular}

"total number of larvae detected per season; ${ }^{* *}$ mean number of larvae detected per season.

Table (2). Seasonal abundance of $O$. dubia larvae on domesticated hosts; quinoa, C. quinoa and saltbush, A. nummularia in 2016 and 2017.

\begin{tabular}{|c|c|c|c|c|c|c|c|c|c|c|c|c|c|}
\hline \multirow{2}{*}{$\begin{array}{c}\text { Domestic } \\
\text { host } \\
\text { species }\end{array}$} & \multirow{3}{*}{$\begin{array}{l}\text { Study } \\
\text { season }\end{array}$} & \multicolumn{12}{|c|}{ Number of larvae } \\
\hline & & \multicolumn{3}{|c|}{ Winter } & \multicolumn{3}{|c|}{ Spring } & \multicolumn{3}{|c|}{ Summer } & \multicolumn{3}{|c|}{ Autumn } \\
\hline \multirow{5}{*}{ 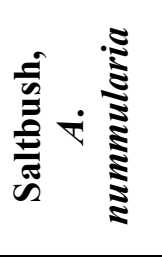 } & & Dec. & Jan. & Feb. & Mar. & April & May & June & July & Aug. & Sep. & Oct. & Nov. \\
\hline & \multirow[t]{2}{*}{2016} & 29 & 32 & 20 & 22 & 19 & 6 & 5 & 2 & 0 & 4 & 4 & 6 \\
\hline & & \multicolumn{3}{|c|}{$81^{*}(27.00)^{* *}$} & \multicolumn{3}{|c|}{$47(15.67)$} & \multicolumn{3}{|c|}{$7(2.33)$} & \multicolumn{3}{|c|}{$14(4.67)$} \\
\hline & \multirow{2}{*}{2017} & 35 & 28 & 23 & 23 & 21 & 10 & 3 & 0 & 1 & 3 & 4 & 4 \\
\hline & & \multicolumn{3}{|c|}{$86(28.67)$} & \multicolumn{3}{|c|}{$54(18.00)$} & \multicolumn{3}{|c|}{$4(1.33)$} & \multicolumn{3}{|c|}{$11(3.67)$} \\
\hline \multirow{4}{*}{ ن } & \multirow{2}{*}{2016} & 13 & 9 & 13 & 5 & 4 & - & - & - & - & - & 1 & 3 \\
\hline & & \multicolumn{3}{|c|}{35 (11.67) } & \multicolumn{3}{|c|}{$9(3.00)$} & \multicolumn{3}{|c|}{ 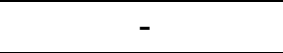 } & \multicolumn{3}{|c|}{$4(1.33)$} \\
\hline & \multirow{2}{*}{2017} & 12 & 11 & 14 & 3 & 4 & - & - & - & - & - & 2 & 1 \\
\hline & & \multicolumn{3}{|c|}{$37(12.33)$} & \multicolumn{3}{|c|}{$7(2.33)$} & \multicolumn{3}{|c|}{-} & \multicolumn{3}{|c|}{$3(1.00)$} \\
\hline
\end{tabular}

"total number of larvae detected per season; ${ }^{* *}$ mean number of larvae detected per season. 
Table (3). Host preference of larval stages of $O$. dubia on quinoa, C. quinoa, and saltbush, A. nummulariain the laboratory.

\begin{tabular}{|c|c|c|c|c|c|c|c|c|c|}
\hline \multirow[b]{3}{*}{$\begin{array}{c}\text { Inspection } \\
\text { date }\end{array}$} & \multicolumn{9}{|c|}{ Number of larvae and pupae } \\
\hline & \multicolumn{3}{|c|}{ A. nummularia } & \multicolumn{3}{|c|}{ In-between } & \multicolumn{3}{|c|}{ C. quinoa } \\
\hline & $\begin{array}{c}\text { Live } \\
\text { larvae }\end{array}$ & $\begin{array}{c}\text { Dead } \\
\text { larvae }\end{array}$ & Pupae & $\begin{array}{c}\text { Live } \\
\text { larvae }\end{array}$ & $\begin{array}{l}\text { Dead } \\
\text { larvae }\end{array}$ & Pupae & $\begin{array}{c}\text { Live } \\
\text { larvae }\end{array}$ & $\begin{array}{c}\text { Dead } \\
\text { larvae }\end{array}$ & Pupae \\
\hline $1^{\mathrm{st}}$ & 0.00 & 0 & 0.00 & 20.00 & 0 & 0 & 0.00 & 0.00 & 0 \\
\hline $5^{\text {th }}$ & 18.67 & 0 & 0.00 & 1.33 & 0 & 0 & 0.00 & 0.00 & 0 \\
\hline $10^{\text {th }}$ & 17.33 & 0 & 0.00 & 0.67 & 0 & 0 & 2.00 & 0.00 & 0 \\
\hline $15^{\text {th }}$ & 17.00 & 0 & 0.00 & 1.33 & 0 & 0 & 1.33 & 0.33 & 0 \\
\hline $20^{\text {th }}$ & 17.00 & 0 & 0.00 & 0.67 & 0 & 0 & 1.67 & 0.33 & 0 \\
\hline $25^{\text {th }}$ & 15.33 & 0 & 1.67 & 1.67 & 0 & 0 & 0.67 & 0.00 & 0 \\
\hline $30^{\text {th }}$ & 10.00 & 0 & 6.67 & 1.00 & 0 & 0 & 0.00 & 0.00 & 0 \\
\hline $35^{\text {th }}$ & 4.00 & 0 & 6.67 & 0.33 & 0 & 0 & 0.00 & 0.00 & 0 \\
\hline $40^{\text {th }}$ & 0.00 & 0 & 4.00 & 0.00 & 0 & 0 & 0.00 & 0.33 & 0 \\
\hline
\end{tabular}

\section{DISCUSSION}

Many of the tussock moths of the family Lymantriidae are defoliators of forest trees (Carvalho, 1972 and Mason, 1974). When abundant enough, the larvae of several species can defoliate an entire tree overnight, resulting in considerable damage to forestry and associated negative economic impacts (Krejmer et al., 2015 and Cui et al., 2011). In Egypt, only two papers have been published reporting the presence of $O$. dubia and this species is among the least recorded species on either wild or economically important plants in the country (Hafez and El-Said, 1970 and Hegazi et al., 1980). The authors reported $A$. halimusas the main host for $O$. dubia larvae. Various species of bushy shrubs have been reported as host plants for $O$. vetusta (Umbanhowar et al., 2003) and O. trigotephras (Ezzine et al., 2010 and 2012).

In its natural habitat, more than one distinct environmental feature favors building up the populations of both $O$. dubia and its host plants. The saline soil along the Egyptian coastal zone constitutes an ideal habitat for the host plants of Orgyia (Hafez and El-Said, 1970). O. dubia has evolved functional adaptive traits that have enabled it to adapt to such conditions. For example, its thermo regulatory potential enables it to withstand the high summer temperatures whereas behavioral traits, such as the $O$. dubia female remaining within the cocoon offers protection for the female and her eggs against high temperatures and desiccation (Seastedt and Crossley, 1981; Denlinger, 2002 and Johnson, 2004). In addition, its larvae have evolved to be able to feed on plant hosts growing on saline soils. According to Castellanos et al. (2011 and 2015), morphological features of lymantriid caterpillars could also have a vital role in their survival. For example, the hairs

Egyptian J. Desert Res., 69, Special Issue, 15-31 (2019) 
that cover $O$. leucostigma larvae could act as a physical defense against predators.

Population of $O$. dubia in the wild is likely to be negatively impacted by endemic natural enemies. Such natural enemies can both hinder the conservation of this species and prevent population outbreaks on crop plants that could otherwise have significant economic impacts. Agrothereutes tunetanus (Haberm.) and Exorista fasciata (Fall.) were recorded as associated parasitoids with O. dubia in Egypt (Hafez and El-Said, 1970). Natural enemies have been reported for other species of Orgyia. For example, Wang et al. (2012) isolated the ecto-larval parasitoid Bracon (Habrobracon) erduos from the larvae of $O$. ericae Germar, whereas eight parasitoid species (seven hymenopterans and one dipteran) had been reported from the same species (Cui et al., 2011).

Anthropogenic activities, including the cultivation of olives and figs within valleys, in addition to the cultivation of $A$. nummularia and C. quinoa outside valleys without any consideration of the environmental impacts of such agricultural expansion, could impact the populations of certain species, including $O$. dubia. According to Williams et al. (2007) and Newbold et al. (2015), habitat conversion, fragmentation, isolation, degradation, and/or loss are the most destructive activities affecting species abundance, diversity, and dispersal, as well as the overall ecosystem (Fischer and Lindenmayer, 2007). Under climate change, ecosystems are also likely to suffer extreme deterioration that will negatively affect species diversities and habitats (Arponen et al., 2005 and Brook et al., 2008). This could be the case for $O$. dubia along the Northwestern coast of Egypt, given that any increase in temperature could negatively impact this species, which is adapted to cooler temperatures (Khin et al., 2006 and Ramakant et al., 2009). Therefore, global warming could become the main driving force for changes that limit the potential of $O$. dubia to adapt to new environmental conditions (Fahrig, 2003; McKechnie and Wolf, 2010 and Segan et al., 2016).

Monocultures of A. nummularia and $C$. quinoa could be another factor that might impact the population of $O$. dubia. Monocultures of these species could provide appropriate conditions for the survival of $O$. dubia during the winter. The modified microclimate within the plant canopy could also have a vital role in alleviating the impact of hot weather on its population during the summer, which could explain the more abundant larval stages of $O$. dubia on its cultivated hosts rather than on its wild hosts.

A. nummularia was found to be preferred by $O$. dubia larvae as a host over $C$. quinoa in the laboratory. In their natural habitat, O. dubia larvae have evolved functional traits that enable them to thrive on naturally occurring $A$. halimus, which itself is adapted for growth on saline soils. Given that $A$. nummularia is also adapted for growth on saline soils, it is likely that this species shares similar traits with A. halimus that render it palatable to $O$. dubia. In addition, given that $C$. quinoais cultivated under a higher level of 
irrigation than A. nummularia, its tissues might not be as saline as those of the latter species, rendering it less palatable to $O$. dubia larvae and, thus, explaining the preference of the larvae for the more saline $A$. nummularia. In coincidence, the inability of $O$. dubia larvae to complete their development on sweet potato had been documented (Hafez and El-Said, 1970). Similarly, in a nutritional index measurement study, Ezzine et al. (2014) reported variations in the mortality and food preference patterns of $O$. trigotephras larvae offered five different shrubs as host plants. The authors linked these differences to variations in the nutritional indices among the plant species. O. leucostigma larvae exhibited faster growth patterns when fed willow plants than when fed box elder plants (Medina et al., 2005).

In terms of the reproduction of lymantriids, previous studies have documented unique behaviors performed by both sexes to successfully mate and deposit eggs. For example, the sedentary or wingless pattern of lymantriid females was previously documented (Tammaru et al., 2002; Lau and MeyerRochow, 2007 and Mishra and Meyer-Rochow, 2008). Nardi et al. (1991) attributed the wingless feature of $O$. leucostigma females to the degeneration of wing epithelium cells. The copulation behavior of O. leucostigma was promoted by sexual pheromones released from the female's scales (Grant et al., 1987). In contrast to the results of the current study, female $O$. pseudotsugata began the oviposition process within 0.5 to $3 \mathrm{~h}$ after mating (Swaby et al., 1987). The moderate level of fecundity of female O. dubia observed during the current study was similar to that observed by Wilson (1991) for O. leucostigma.

Based on results of the current study, future studies of $O$. dubia under both laboratory and natural conditions are required to (i) explore the precise details of the biology, behavior and ecology of this species; (ii) determine its role and interactions in the food webs under natural ecosystem conditions and (iii) clarify the impacts of climate change on this species and those species with which it interacts (e.g. natural enemies). Thus, given the reduction in the natural vegetation diversification along the Northwestern coast of Egypt as a result of increased agriculture, substantial efforts might be needed to conserve all wild species including $O$. dubia in this region.

Egyptian J. Desert Res., 69, Special Issue, 15-31 (2019) 


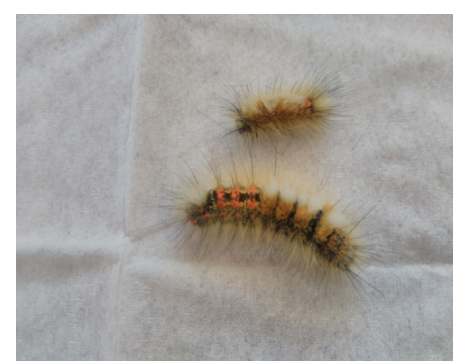

Larval stage

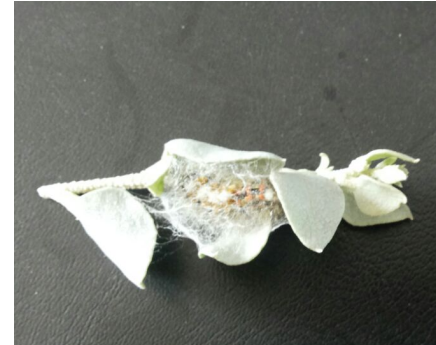

Larva weaves a cocoon
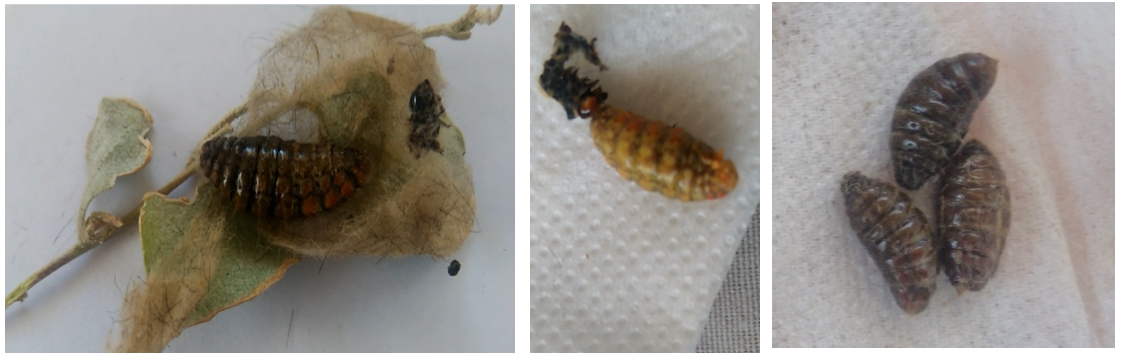

Female pupae

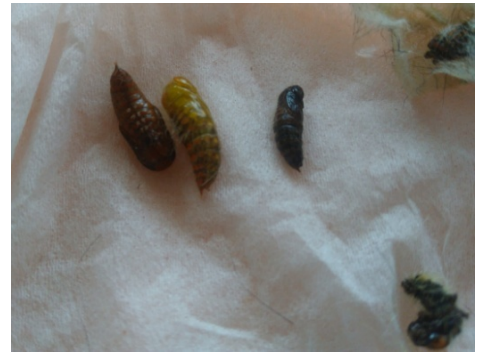

Male pupae

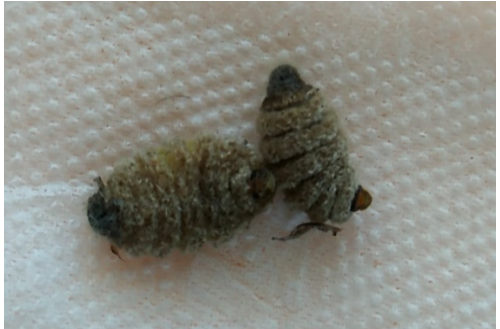

Female moths

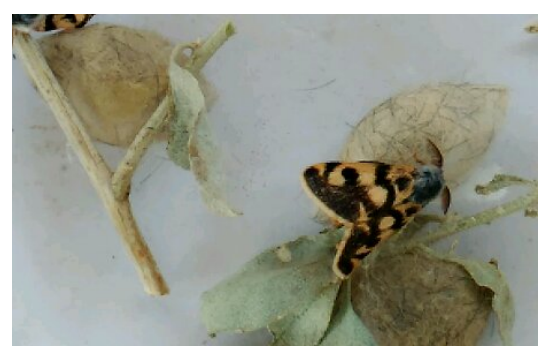

Male moths

Egyptian J. Desert Res., 69, Special Issue, 15-31 (2019) 


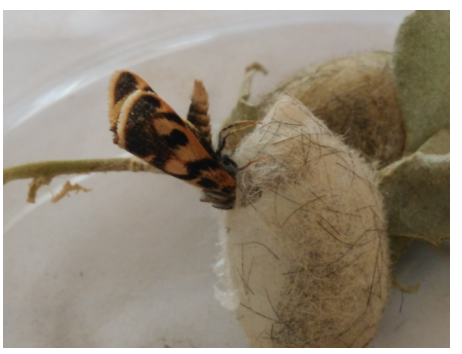

Male moth penetrates female cocoon

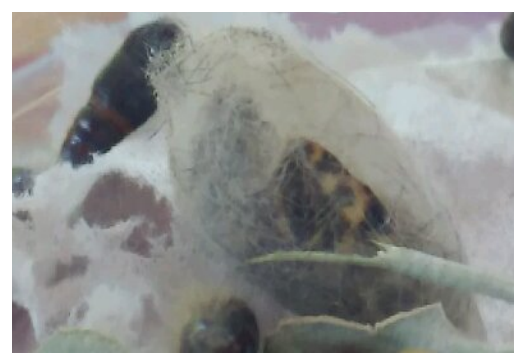

Male within female cocoon

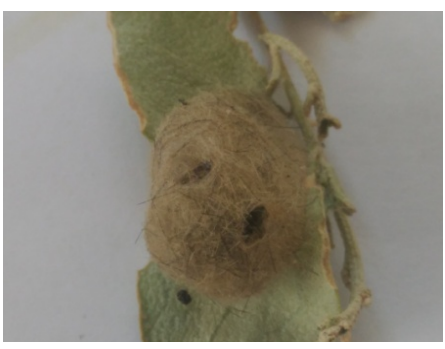

Entrance and exit holes made by male moth
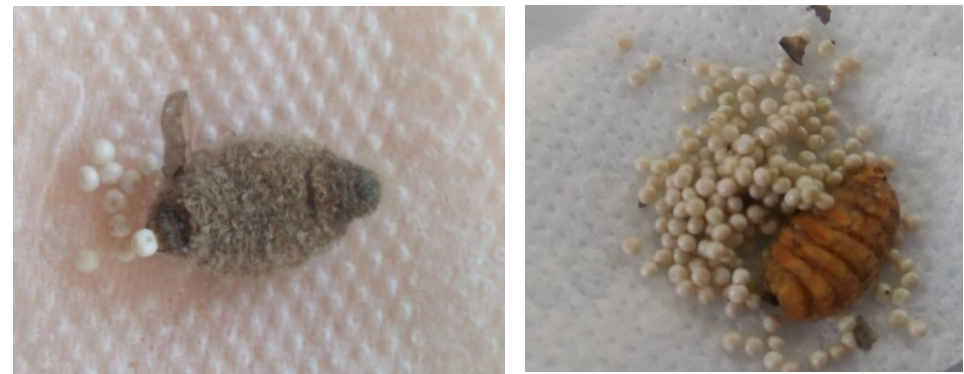

Female moth lays eggs
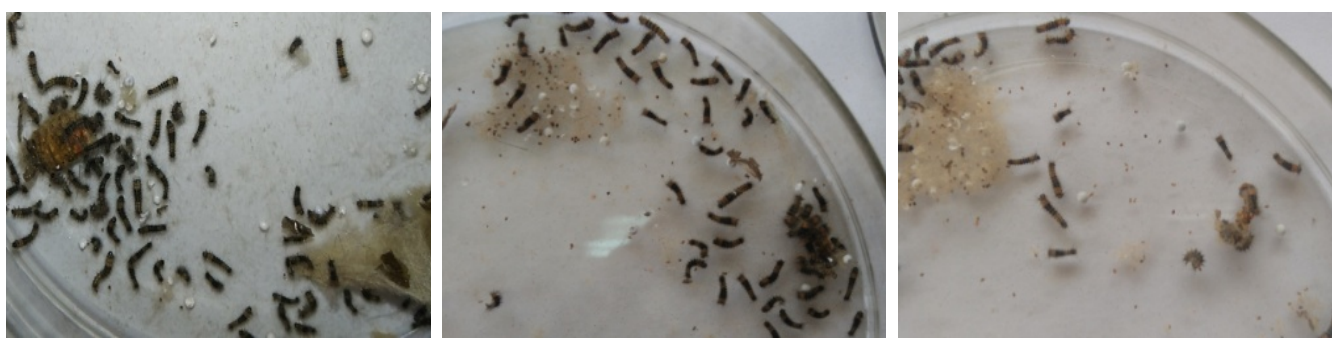

Aggregation of newly hatched larvae consuming the body of their mother

Fig. (2). Life cycle of O.dubia.

Egyptian J. Desert Res., 69, Special Issue, 15-31 (2019) 


\section{ACKNOWLEDGEMENT}

The authors thank Prof. Dr. Monir M. El-Husseini, Department of Econ. Entomology and Pesticides, Faculty of Agriculture, Cairo University for his scientific support and revision of the manuscript.

\section{REFERENCES}

Alicata, M.L., G. Amato, A. Bonanno, D. Giambalvo and G. Leto (2002). In vivo digestibility and nutritive value of Atriplex halimus alone and mixed with wheat straw. J. Agric. Sci., 139: 139-142.

Arponen, A., R.K. Heikkinen, C.D. Thomas and A. Moilanen (2005). The value of biodiversity in reserve selection: Representation, species weighting, and benefit functions. Conserv. Biol., 19 (6): 2009-2014.

Brook, B., N. Sodhi and C. Bradshaw (2008). Synergies among extinction drivers under global change. Trends Ecol. Evol., 23 (8): 453-460.

Carvalho, J.P. (1972). Contribution to the knowledge of Orgyia mixta (Lep., Lymantriidae) in Angola. Serie Cientifica Instituto de Investigaçao Agronómica de Angola, 25: 1-25.

Castellanos, I., P. Barbosa, I. Zuria, T. Tammaru and M. Christman (2011). Contact with caterpillar hairs triggers predator-specific defensive responses. Behav. Ecol., 22 (5): 1020-1025.

Castellanos, I., I. Zuria, P. Barbosa and A. Caldas (2015). Morphology and antipredator behavior in larval Orgyia leucostigma (Lepidoptera: Lymantriidae). J. Lepid. Soc., 69 (4): 327-331.

Cui, Y., M. Sheng, Y. Luo and S. Zong (2011). Emergence patterns of Orgyia ericae (Lepidoptera: Lymantriidae) parasitoids. Rev. Colomb. Entomol., 37 (2): 240 - 243.

Denlinger, D.L. (2002). Regulation of diapause. Annu. Rev. Entomol., 47: 93122.

El Bastawesy, M.A., R.R. Ali and A.H. Nasr (2008). The use of remote sensing and GIS for catchments delineation in Northwestern Coast of Egypt: an assessment of water resources and soil potential. Egypt. J. Remote. Sens. Space. Sci., 11:3-16.

El-Zanaty, R.I.A., A.A. Abdel-Hafez, I. Abdel-Gawadk, M.H.M. El-Morsy, and H.M.A. Abusaief (2010). Effect of location and growth season on the productivity and quality of some range plants in Wadi Halazien in the North Western Coast in Egypt. Nat. Sci., 8 (7): 50-70.

Ezzine, O., M.L. Ben Jamaa, S. M'nara and S. Nouira (2010). Bioécologied' Orgyia trigotephras (Boisduval, 1829), (Lepidoptera, Lymantriidae) à Jebel Abderrahman, Cap Bon (Nord Est de la Tunisie). IOBC/WPRS Bull., 57: 123-127. 
Ezzine, O., M. Dahmouni, M.L.B. Jamaa, G. Mabrouk and S. Nouira (2012). Relationships between the polyphagous Orgyia trigotephras (Lepidoptera, Lymantriidae) larvae, a cork oak pest, and its host plants in Tunisia. IOBC/WPRS Bull., 76: 271-278.

Ezzine, O., Y. Mannai, S. Nouira and M.L. Ben Jamaa (2014). Nutritional indices of Orgyia trigotephras Boisduval, 1829 (Lepidoptera, Lymantriidae) on five shrub species. IOBC/WPRS Bull., 101: 187194.

Fahrig, L. (2003). Effects of habitat fragmentation on biodiversity. Annu. Rev. Ecol. Evol. Syst., 34 (1): 487-515.

FAOSTAT (2013). Quinoa area and production in the World. Available online: http://www.fao.org

Fischer, J. and D.B. Lindenmayer (2007). Landscape modification and habitat fragmentation: a synthesis. Glob. Ecol. Biogeogr., 16 (3): 265-280.

Grant, G.G., D. Frech, L. MacDonald, K.N. Slessor and G.G.S. King (1987). Copulation releaser pheromone in body scales of female white marked tussock moth, Orgyia leucostigma (Lepidoptera: Lymantriidae): identification and behavioral role. J. Chem. Ecol., 13 (2): 345-356.

Hafez, M. and L. El-Said (1970). On the bionomics of Orgyia dubia judaea Stgr. (Lepidoptera; Lymantriidae). Bull. Soc. Entomol. Egypt., 53: 161-183.

Hegazi, E.M., K.W. James, J.R. Goodin and K.N. David (1980). Field observations on arthropods associated with Atriplex halimus in Egypt. J. Arid. Environ., 3: 305-308.

Johnson, D.M. (2004). Life history and demography of Cephaloleia fenestrate (Hispinae: Chrysomelidae: Coleoptera). Biotropica, 36 (3): 352-361.

Khin, M.M., T. Myint T.L. and Tun (2006). Natural incidence, biological study, and control of some insect pests in Terminalia belerica. Proc. Ann. Res. Conf., (Forestry Sciences), Yangon, Myanmar. 26-28 May, p. 260-273.

Krejmer, M., I. Skrzecz, B. Wasag, B. Szewczyk and L. Rabalski (2015). The genome of Dasychira Pudibunda Nucleo polyhedrovirus (DapuNPV) reveals novel genetic connection between baculoviruses infecting moths of the Lymantriidae family. BMC Genomics, 16 (759).

Lau, T.F. and V.B. Meyer-Rochow, (2007). The compound eye of Orgyia antiqua (Lepidoptera: Lymantriidae): sexual dimorphism and light/dark adaptational changes. Eur. J. Entomol., 104 (2): 247-258.

Leddy, P.M., T.D. Paine and T.S. Bellows (1993). Ovipositional preference of Siphoninus phillyreae and its fitness on seven host plant species. Entomol. Exp. Appl., 68 (1): 43-50.

Mansour, N.A. and I.A. Imam (2017). Spatial distribution of Hymenoptera under the rain-fed conditions of Habis valley, Northwestern Coast, Matrouh Governorate, Egypt. J. Bio. Env. Sci., 11 (1): 26-36.

Egyptian J. Desert Res., 69, Special Issue, 15-31 (2019) 
Mason, R.R. (1974). Population change in an outbreak of the Douglas-fir tussock moth, Orgyia pseudotsugata (Lepidoptera: Lymantriidae), in central Arizona. Can. Entomolo., 106 (11): 1171-1174.

McKechnie, A.E. and B.O. Wolf (2010). Climate change increases the likelihood of catastrophic avian mortality events during extreme heat waves. Biol. Lett., 6 (2): 253-256.

Medina, R.F., P. Barbosa and K. Waddell (2005). Parasitism levels in Orgyia leucostigma feeding on two tree species: implications for the slowgrowth- high- mortality hypothesis. Entomol. Exp. Appl., 115 (1): 193-197.

Mishra, M. and V.B. Meyer-Rochow (2008). Eyes of male and female Orgyia antiqua (Lepidoptera; Lymantriidae) react differently to an exposure with UV-A. Micron, 39 (4): 471-480.

Nardi, J.B., G.L. Godfrey and R.A. Bergstrom (1991). Programmed cell death in the wing of Orgyia leucostigma (Lepidoptera: Lymantriidae). J. Morphol., 209 (1): 121-131.

Newbold, T., L.N. Hudson, S.L.L. Hill, S. Contu, I. Lysenko et al. (2015). Global effects of land use on local terrestrial biodiversity. Nature, 520: $45-50$.

Ramakant, M., A. Mukhtar and F. Mohd (2009). Tulsi (Ocimum sanctum): a new host of Orgyia postica Walker (Lepidoptera: Lymantriidae). Ind. For., 135 (11): 1598-1599.

Seastedt, T.R. and D.A. Crossley (1981). Microarthropod response following cable logging and clear-cutting in the southern Appalachians. Ecol., 62: 126-135.

Segan, B.D., A.K. Murray and J.E.M. Watson (2016). A global assessment of current and future biodiversity vulnerability to habitat loss-climate change interactions. Glob. Ecol. Conserv., 5: 12-21.

Sewidan, A.S. (1978). Water budget analysis for the northwestern coastal zone. PhD Thesis, Fac. Sci., Cairo Univ., 179 pp.

Swaby, J.A., G.E. Daterman and L.L. Sower (1987). Mating behavior of Douglas-fir tussock moth, Orgyia pseudotsugata (Lepidoptera: Lymantriidae), with special reference to effects of female age. Ann. Entomol. Soc. Am., 80 (1): 47-50.

Tammaru, T., T. Esperk and I. Castellanos (2002). No evidence for costs of being large in females of Orgyia spp. (Lepidoptera, Lymantriidae): larger is always better. Oecologia, 133 (3): 430-438.

Umbanhowar, J., J. Maron and S. Harrison (2003). Density-dependent foraging behaviors in a parasitoid lead to density-dependent parasitism of its host. Oecologia, 137 (1): 123-130.

Wang, Y., X. Chen and J. He (2012). A new species of Bracon (Hymenoptera: Braconidae) parasitic on larvae of the pest Orgyia ericae Germar (Lepidoptera: Lymantriidae) in northern China. Entomological News, 122 (1): 74-78. 
Williams, J.W., S.T. Jackson and J.E. Kutzbach (2007). Projected distributions of novel and disappearing climates by 2100 AD. Proc. Natl. Acad. Sci., 104 (14): 5738-5742.

Wilson, L.F. (1991). Location and condition of white marked tussock moth (Lepidoptera: Lymantriidae) cocoons in a Michigan black walnut plantation. Great Lakes Entomol., 24 (3): 153-157.

Yousif, M., A. El Sayed and B. Ahmed (2013). Assessment of water resources in some drainage basins, north-western coast, Egypt. Appl. Water. Sci., 3: 439-452.

Egyptian J. Desert Res., 69, Special Issue, 15-31 (2019) 
وصف الموئل والتفضيل العوائلي وسلوك التزاوج لفراشة الكتلة العشبية

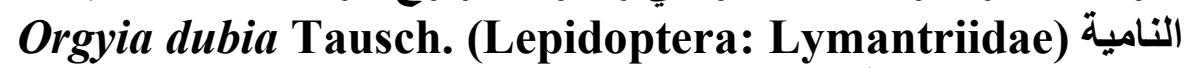
في الساحل الثمالي الغربي المصري

$$
\text { أحمد إبراهيم إمام" وأماني نبيه منصور }
$$

قسم وقاية النبات، مركز بحوث الصحر اءو، المطرية، القاهرة، مصر

Orgyia dubia (Lepidoptera: Lymantriidae) تعتبر فر اشة الكتلة العشبية النامية

من الأنواع الحشرية النادرة بمنطقة الساحل الثمالي الغربي المصرية الثرية وقد أحدثت الأنشطة البشرية

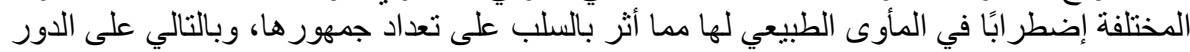

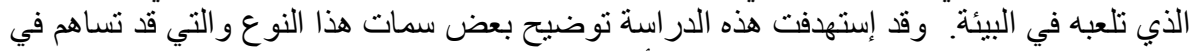

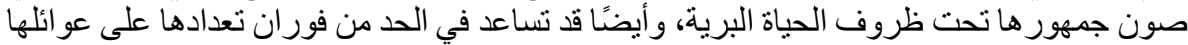

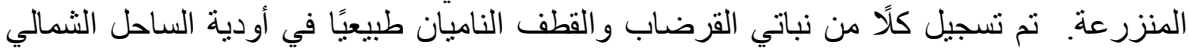

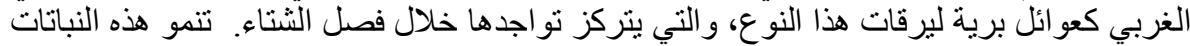

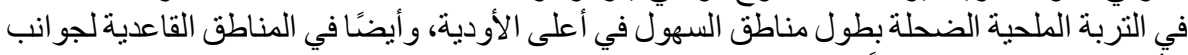

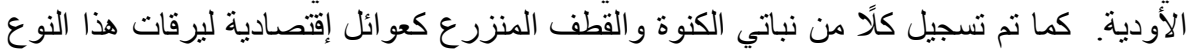

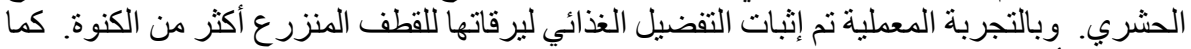

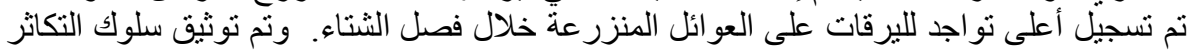

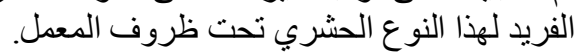

Egyptian J. Desert Res., 69, Special Issue, 15-31 (2019) 